\title{
Fiber from Milk Byproducts - A New Dimension
}

\author{
Neha Chauahn*, Nisha Arya and Suman Sodhi \\ Department of Textile and Apparel Designing, I.C College of Home Science, CCSHAU, \\ Hisar-125004, Haryana, India \\ *Corresponding author
}

\begin{tabular}{|l|}
\hline K e y w o r d s \\
Milk fiber, Casein, \\
Skimmed milk, \\
Protein, Micelles, \\
Lubricate, \\
Comfortable
\end{tabular}

\section{Introduction}

Milk protein fibre is made out of skimmed milk. Main components of this fibre are casein proteins, drawn from the cow's milk. It is responsible for the white, opaque appearance market.

\section{A B S T R A C T}

Milk protein fibre is made out of skimmed milk. Main components of this fibre are casein proteins, drawn from the cow's milk. It is responsible for the white, opaque appearance of milk in which it is combined with calcium and phosphorus as clusters of casein molecules, called micelles. This fiber contains eighteen types of amino-acids extracts that helps in the nourishments of the skin and makes it healthier. Milk protein fibre is a blend of nature, science and technology that has benefits of natural as well as synthetic fibre. Milk fiber was invented in 1930s in both Italy and America and was called milk casein. A new generation of innovative fiber and a kind of synthetic fiber made of milk casein through bioengineering method with biological health care function and natural and long-lasting antibacterial effect, which has got valid certification for international ecological textile certification. It is hygienic, flexible, smooth, sheen, renewable, biodegradable and eco friendly fabric but it has low durability and is expensive. The mass specific resistance of milk protein fiber is large. Milk protein fiber is bulky and it is easy to open. The cohesion force is relatively weaker. Casein fibres resemble wool in having a soft warm handle. Casein fibres provide good thermal insulation. They are resilient like wool. The process of making milk protein fiber include desizing, scouring, bleaching, dyeing, drying, printing, finishing and carbonising. Milk fibers can be blended with many other fibers like cotton, cashmere, silk etc. The healthy nature of milk fiber is considered as a perfect material for manufacturing of underwear's. Milk casein protein is considered as a main ingredient of milk protein fiber, which can lubricate the skin. The milk proteins contain the natural humectants factor which can help to maintain the skin moisture, to reduce the wrinkles and to smoothen the skin. Milk fiber can be used for making of garments, beddings, socks, sportswear's, new born's bath towels etc. The milk protein fiber is a healthy and comfortable fiber that makes us feels better and will certainly become popular in the

of milk in which it is combined with calcium and phosphorus as clusters of casein molecules, called as micelles. Milk fibre contains eighteen amino-acids and has the advantages of natural fibre combined with synthetic fibres. The $\mathrm{pH}$ of milk fibre is 6.8 
which is same as human skin (Hariram, 2011). Milk protein fibre is a blend of nature, science and technology that has benefits of natural as well as synthetic fibre. It is most comfortable and has excellent water transportation and airpermeability. It biodegrades and is renewable. The major uses of casein until the 1960s were in technical, non-food applications such as adhesives for wood, paper coating, leather finishing and in synthetic fibres, as well as plastics for buttons, buckles etc. The present age in textiles is more and more to the utilization of synthetic fibres.

Nevertheless, the protein has already become established in several industrial spheres, and there is certainly a surplus of skim milk which in many parts of the world is assessed at a very low price and is available for textile purposes. Other vegetable proteins in nuts and soya bean are also available and have been converted into filaments but casein stands from the point of view of abundance, good colour and the possibility of isolating it without molecular breakdown (Diamond, 1939).

\section{History}

During the First World War, when the Germans were looking out for some newer sources of fabric, they discovered milks potential for cloth. The solutions of casein were spun experimentally to form fibres and it was forced through the jets into hardening baths forming solid filaments in which the long casein molecules had been given sufficient orientation to hold together in typical fibre form. These early fibres were of little value. They were brittle, hard and lacked the resilience and durability (Hariram, 2011). During early 1930's an Italian chemist Antonio Feretti, experimented with casein fibres to try and overcome their drawbacks. He was successful in making casein fibres which were pliable and had many properties associated with wool. Feretti sold his patents to large Italian's rayon firm (Snia Viscosa) who manufactured casein fibres under the trade name of Lanital at large scale.

\section{What is casein fibre?}

A new generation of innovative fiber and a kind of synthetic fiber made of milk casein through bio-engineering method with biological health care function, natural and long-lasting antibacterial effect, which has got valid certification for international ecological textile certification of Oeko-Tex Standard 100 Authentication approved it in April 2004. It is most comfortable with excellent water transportation and air-permeability. It is also more healthy, light, soft and colorful being resistant to fungus, insects and ageing (Saluja, 2010).

Constitutionally casein has a striking similarity to wool. It is a phospho-protein built up from a number of amino acids.

\section{Advantages of casein fiber}

Milk protein is hygienic and flexible.

It is highly smooth, sheen and delicate.

It is moisture absorbent, permeable and heat resistant.

It is colour fast and easily dyeable and requires no special care because of its natural protein base. It can be blended with other fibre.

It is renewable, biodegradable and ecofriendly fabric.

\section{Disadvantages of casein fiber}

It gets wrinkled easily after washing and needs to be ironed every time. 
It has a low durability though caseins can be laundered with care same as wool but they lose strength when wet and must be handled gently.

It is expensive.

They cannot be kept damp for any length of time due to quick mildewing (Anonymous, 2010).

\section{Types of casein fibre}

Commercial casein is generally made in two forms:

Rennet Casein

Acid Casein

Acid Casein: is used for spinning of textile fibres. Acid casein may be made either by precipitation from milk by mineral acids, or by separation after allowing the milk to sour. The dried product is made into a solution using dilute caustic alkali.

The process followed in manufacturing is similar to that of other synthetic fibres, the solution being extruded through fine holes into a coagulating bath. The chemicals used, however, are different and an essential part of the process consist a treatment to render the casein fibres insoluble, and resistant to the various textile baths.

Rennet Casein: Rennet casein is used for accessories.

\section{Process of casein fibre manufacturing}

Take sour milk, a raw material that is otherwise wasted and unmarketable.

Process it natural until it becomes the most basic protein in the milk- a protein called casein.
The casein is dissolved in water that contains about 2 percent by weight of alkali to make a viscous solution with 20 to 25 percent protein. (www.Kpmg.be)

The filtered casein solution is pumped by a metering pump through a platinum-gold alloy disc or spinneret which has thousands of fine, accurately placed and uniform holes.

The solution, streaming from the holes of the spinneret is immersed in water that contains an acid.

The acid neutralizes the alkali used to dissolve the casein. The small continuous fibers are then stretched, treated in various solutions and collected by the spinning machinery. Kapde, 2011

The tensile strength of the yarn (just like regular thread) is enhanced by stretching the fiber while it is being tanned with aluminum salts and formaldehyde.

A further treatment is needed in order to make the fiber resist to boiling bath commonly used in wool dyeing (Kapde, 2011).

\section{Wet Processing}

\section{Desizing}

It is done to break down the size. Enzyme products may be used, preferably at $\mathrm{pH} 4.0$ to 6.0 .

If water soluble sizes have been used, desizing is not necessary.

\section{Scouring}

It is mainly to remove the impurities present in the fiber. Synthetic detergents should be used, preferably under acidic conditions (Blogaash, 2011). 


\section{Bleaching}

In common with all wet processing, bleaching should be carried out if possible under weakly acidic conditions, as casein fibers retain maximum strength and minimum swelling under these conditions. It improves whiteness by removing natural colour and remaining impurities in the fibre. If alkaline processing is used, it must be followed y careful washing and acidification with acetic acid.

\section{Dyeing}

Casein absorbs moisture readily and does not have a highly orientated structure. Dyes can penetrate into the fibre without difficulty. In general, casein can be dyed with the dyestuffs used for wool. Acid, basic, direct and disperse dyes are used where good washing fastness is not a prime essential.

\section{Drying}

After dyeing, loose stock and yarns may be centrifugally hydro-extracted before being dried in conventional plant. Woven fabrics can be hydro-extracted by open width suction machine or by centrifuging in open width. It is essential to allow an adequate shrinkage from grey to finished dimensions.

\section{Printing}

Casein blend fabrics can be printed very effectively. Good results necessitate through preparation. If singeing is needed a light treatment with a low burner will be sufficient. A thorough scour is essential. Casein fibre is generally white and bleaching is not usually necessary. If required, a mild perborate or peroxide bleach should be used under controlled conditions. After treatment the fabric should be dried on the tins under minimum warp tension followed by stentering to a stable width. Fabrics containing casein may be printed by block, roller, surface roller, and modified paper printer methods. (Blogaash, 2011)

\section{Finishing}

Milk protein fiber's products should be after treated, such as crease-resist finishing and softening to keep it soft and delicate.

\section{Crease resistant finishing}

The crease resistant finishing agents have more choices and the environmental finishing with good crease resist effect should be selected.

\section{Softening}

During dyeing and producing, the milk protein fiber feels hard after crease resistant finishing in high temperature and tension. In order to make fabric full and soft, softening is needed and softening with a suitable softening agent is an effective method (Blogaash, 2011).

\section{Carbonising}

The process is the same for cloth as for loose wool. The vegetable matter is destroyed by soaking the cloth in weak acids and then heating in an oven. Casein will withstand the carbonising treatment when carried out with the minimum strength of sulphuric acid necessary for the effective removal of vegetable matter. After treatment the material should be well rinsed and adjusted to $\mathrm{pH} 4$ with sodium bicarbonate. Carbonising may be carried out before or after dyeing. If done after dyeing it eliminates the general tendency of the process to cause unlevel dyeing (Blogaash, 2011).

\section{Properties}

The mass specific resistance of milk protein fibre is large. 
Casein Milk Protein Fiber (Yang, 2012)

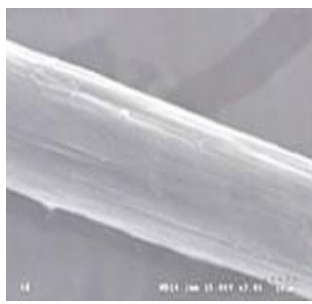

Vertical

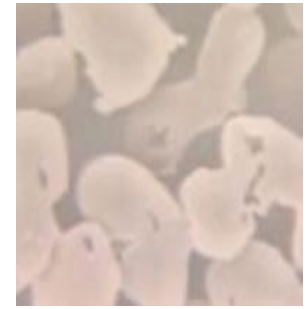

Horizontal

\section{PRODUCTION PROCESS}


Main technical indexes of milk protein fiber

\begin{tabular}{|l|l|l|}
\hline No & Properties & Index \\
\hline 1 & Fiber tenacity (dtex) & $0.8-3$ \\
\hline 2 & Breaking tenacity (dtex) & $2.5-3.5$ \\
\hline 3 & Breaking elongation rate (\%) & $25-35$ \\
\hline 4 & Modulus (cN/dtex) & $60-80$ \\
\hline 5 & Standard moisture regain (\%) & 5.5 \\
\hline 6 & Specific resistance & $1.5 \times 104$ \\
\hline 7 & Static friction coefficient & 0.187 \\
\hline 8 & Dynamic friction coefficient & 0.214 \\
\hline 9 & Color fastness to washing & $4-5$ grade \\
\hline 10 & Fastness to crocking & $4-5$ grade \\
\hline 11 & Fastness to perspiration & $4-5$ grade \\
\hline 12 & Color fastness to light & 4 grade \\
\hline 13 & Pilling resistance & 3 grade \\
\hline
\end{tabular}

Moisture regain of milk protein fibre is about $16 \%$.

Milk protein fibre is bulky and it is easy to open. The cohesion force is relatively weaker.
Casein fibres resemble wool in having a soft warm handle.

The fibres are naturally crimped and yarns have a characteristic warmth and fullness 
handle. Casein fibres provide good thermal insulation. They are resilient like wool (www.swicofil.com.2015).

\section{Milk fibers blended with other fibers}

Milk fibers are blended with many other fibers like cotton, cashmere, silk etc. When milk fibre is combined with these fibres, the ensuing fabric adopts some new characteristics of other fibres but one quality that is preserved in all the blend is of being a fit and eco-friendly fibre.

\section{Blend with silk and bamboo}

It is the cool, free of moisture, sweat exhibitor, comfy and aerated fibre which has the chattel of coolness. It is soft and silky with an attractive sheen. The dazzling grace is reflected in the personality on wearing this fabric. (www.fiber2fashion.com, 2010)

\section{Blend with wool and cashmere}

It is the heat protective fibre. Milk fibre has a type of three-dimensional arrangement ie. With permeability and humidity resistant properties, the milk fibre when combined with wool and tepid cashmere, turns out to be extremely warm material and it is comfy and healthy fabric. Blended fabrics combining milk protein fiber with cashmere increases garment strength and glossiness.

\section{Blend with cotton and cashmere}

It is suitable for comfortable under garments. The milk protein contains ample of amino acid and moisture protecting genes. It is competent enough of resisting microorganisms. The natural cotton and cashmere fibres also contain similar characters and combining with milk fibre, these traits churn together to make healthy and comfy under clothing (Khanum, 2013).

\section{Care of casein fibers}

\section{Washing}

Garments containing casein fibers should be washed with care and treated very gently. High temperature and strong acid or alkaline conditions must be avoided. Neutral detergents are preferable for washing. Wash by hand or washing machine (in bag and weak force) under $35^{\circ} \mathrm{C}$. Don't use chlorine bleach (wash with chlorinated washing powder is not recommended) (Hariram, 2011).

\section{Drying}

Garments should be dried as wool, care being taken to avoid high temperatures. Don't wring out or hang dry when the moisture content is over 50\% (Hariram, 2011).

\section{Ironing}

The full, soft handle of garments containing casein will be maintained if they are slightly damp or almost dry before being ironed or pressed. Wool settings should be used at ironing in medium temperature (or with steam) (Hariram, 2011).

\section{Dry cleaning}

Casein is not affected by dry cleaning solvents and garments and can be dry cleaned readily as wool (Hariram, 2011).

\section{Uses of casein fibres}

The healthy nature of milk fiber is considered as a perfect material for manufacturing of underwear's. Milk casein proteins are considered as a main ingredient of milk protein fiber, which can lubricate the skin. The milk proteins contain the natural humectants factor which can help to maintain 
the skin moisture to reduce the wrinkles and to smoothen the skin - which may help to realize the people of taking milk bath (Kiron, 2013). Casein fibre use in children's garments, t- shirts, sweaters, women's garments, under clothing's, uniforms, beddings, socks, sportswear's, and eye masks, dog garments, new born's bath towels etc.

\section{Casein fibers were commercially produced in various countries with trade names such as}

Aralac and Caslen (U.S.A)

Lactofil (Holland)

Cargan (Belgium)

Tiolan (Germany)

Silkool (Japan)

Fibrolane (England)

Lanital and Merinova in Italy

Wipolan in Poland

All through the years, experts have been devoted to the researches on improved fibers and at present they have succeeded in the development of the globally advanced milk protein fiber, a milestone in the international textile industry.

Being the optimal combination of nature and hi-tech, it is more accommodated to the needs of people's modern lifestyle. So far clothing made from milk is expensive so it has a limited market however a handful of companies are experimenting with this fabric.

Milk Fabrics are so skin-friendly that it itself makes us feel better. Advances in science are also helping to fill the green wardrobe of tomorrow. Sweaters are knit from spun milk protein.

These textiles are where the future innovations are going to lie. It's taking fashion to a whole new level where it never really existed before- where it's not just about looking good. It's about feeling good, too. The milk protein fiber is a fresh product as a superior green, healthy and comfortable fiber, which will certainly become popular goods in the market.

\section{References}

Blogaash, B. 2011. A study on casein fiber. M.Sc. Apparel Technology \& Management. http://blogaash.blogspot.in/2011/10/studyon-casein-fiber.html.

Bo, Z. 2007. Development Regenerated Milk Protein Fiber/Cashmere Wool Blended Yarn. Zhongyuan Institute of Technology, Zhengzhou/China retrieved from cnki.com.cn

Bo, Z. 2009. Milk Regenerate Protein Fiber Characteristics and Its Application and Development In Nonwovens. The Journal of The Technical textiles TS172 retrieved from cnki.com.cn

Cho, S.W., Skrifvars, M., Hemanathan, K., Mahimaisenan, P., Adekunle, K., 2014.Regenerated cellulose fibre reinforced casein films. Journal of Macromoleular Research. 22(7):701-709.

Choudhury, M., Talukdara, B., Dassb, N.N., Baruah, K.C., Devi, D., 2015. Impact of BSA and casein on chemical modification of muga silk fiber. The Journal of The Textile Institute, DOI: http://dx.doi.org/10. 1080/00405000.2015.1034926

GUNG Ai-hua, ZHANGE jian-fei, Zhange Chunjuan (Tianjin polytechnic university, Tianjin 300160) retrieved from cnki.com.cn

Hariram, A. 2011. A study on casein fiber. M.Sc. Apparel Technology and Management. http://www.slideshare.net/akaashi20/astudy-on-casein-fiber

http://f2fauthor.articlealley.com/milk-fabrics-asmarter-way-to-absorb-milk-nutrients1813977.html

http://www.articlesnatch.com/blog/What-Is-MilkFiber-/1774427\#gsc.tab=0 (Retrieved on 10-Sep-2015).

http://www.georgeweil.com/fact_file/anne_cook.a spx (Retrieved on 26-AUG-2015).

http://www.kpmg.com 
http://www.patrickyarns.com/greenrecycled/milk-protein/ (Retrieved on 2-Sep2015).

http://www.usdairy.com

https://en.wikipedia.org/wiki/Casein (Retrieved on 26-AUG-2015).

https://www.linkedin.com/pulse/milk-caseinfiber-manufacturing-process-applicationprajes-ghosh(Retrieved on 26-AUG-2015).

Jia, Z., Du, S. and Tian, G. 2007. Surface modification of acrylic fiber by grafting of casein. Journal of Macromolecular Science. 44(3): 299-304.

Jing, L. K., Xin, J.H., Zhong, S.C., 2008. Structure and Properties of Milk Protein Fiber. The Journal of the Textiles Research. Zhongyuan institute of technology, Zhengzhou, Henan 450007, China retrieved from cnki.com.cn

Khanum, H. and Shivaprakash, A. V. 2013. Product development of blended milk casein knitted garment. Academic Journal. 41(2):50.

Ming, R.C., Yong, Y.J. and Ni, W. 2008. Study on the composition and structure of the milk protein fiber. College of Textile, Donghua University, Shanghai 20005, China. Journal of Xi'an Polytechnic University.

Ming, R.C., Yong, Y.J. and Ni, W. 2007. Analysis on Properties of Fabrics Blended with Milk Protein Fiber. Donghua University, Shanghai 201620, China. Shandond Textile Science \& Technology.

Nigmatova, F., Kasimova, A. and Shin, E. 2012. Deformation properties of knitted fabrics from blended yarn based on cotton and polyacrylonitrile fibres. Academic Journal. $44(1): 21$
Poojari, B. 2014. https://prezi.com/tymhchktcbni/ casein-fiber/(Retrieved on 26-AUG-2015).

Products of Doshi group: Milk fiber-Shanghai Zhengjia. 2012. Doshi Group. Retrieved March 1, 2016, from http://www.doshigroup.com

Sevsenko, M. 2011. The Futurists: Clothing from milk: The latest in green technology: Spinning thread from milk byproducts. GlobalPost. Retrieved from http://www.globalpost.com.

Sohail, S.S., B. Wang, M. A. S. Biswas, and J. H. Oh, J. Food Sci., 71, C255 (2006).

Southward, C. 1998. Dairy products/casein products. In J. E. Packer, J. Robertson, \& $\mathrm{H}$.

What is milk fiber? (2011, February 25). Exchanging Fire. http://exchangingfire. wordpress.com (Retrieved on 26-AUG2015).

Whittier, E.O. and Gould, S.P., 1940. Making Casein Fiber. Industrial \& Engineering Chemistry. 32(7): 906-907.

Wihodo, M. and Moraru, C.I. 2013. Physical and chemical methods used to enhance the structure and mechanical properties of protein films. Journal of Food Science. 114 (3): 292-302.

Xiurong, F. and Zengge, G. 2012. Structure and Application of Milk Protein Fiber. $J$. Guangdong Chemical Industry, 39(2):244245.

Yang, Y. and Reddy, N. 2012. Properties and potential medical applications of regenerated casein fibers crosslinked with citric acid. International Journal of Biological Macromolecules. 51(1-2):37-44.

\section{How to cite this article:}

Neha Chauahn, Nisha Arya and Suman Sodhi. 2018. Fiber from Milk Byproducts - A New Dimension. Int.J.Curr.Microbiol.App.Sci. 7(04): 1257-1264.

doi: https://doi.org/10.20546/ijcmas.2018.704.140 